\title{
VARIASI METODE PEMBELAJARAN SEJARAH KEBUDAYAAN ISLAM (SKI) DI MTS MIFTAHUL ULUM WEDING BONANG DEMAK
}

\author{
Eni Riffriyanti \\ Universitas Islam Sultan Agung (UNISSULA) Semarang \\ ummulubna76@gmail.com
}

\begin{abstract}
The main problem in this research is how the implementation of strategy of the teacher in selectif the method variation on the learning of SKI in MTs. Miftahul Ulum Weding Bonang Demak and how is the positive response of learners to the variation of methods on learning SKI in MTs. Miftahul Ulum Weding Bonang Demak.

The method used in this study is a qualitative method, data collection techniques used by researchers are interviews, observation, and documentation.

The result s of this study are: 1) there are variations of strategy used by the teacher on learning SKI in MTs. Miftahul Ulum, the consideration of using strategies are: the healt condition of learners; the psychological condition of learners; the scheduled time for SKI subjects; the contens of the SKI lesson material to be delivered. 2) positive response of learners to the variation of methods on learning SKI in MTs. Miftahul Ulum is shown by the spirit of learning when the lesson of SKI is delivered by using variation of learning method, the learners are not sleepy when subjects of SKI are delivered with varied method, they feel good and not bored when SKI lesson is presented by using varied method, lacking of the subject of SKI organized by the school, and felt the need to add additional hours of SKI subject.
\end{abstract}

Keywords: method variation, learning SKI

\begin{abstract}
ABSTRAK
Masalah utama dalam penelitian ini adalah bagaimana strategi guru dalam memilih variasi metode pada pembelajaran SKI di MTs. Miftahul Ulum Weding Bonang Demak dan bagaimana respon peserta didik terhadap variasi metode pada pembelajaran SKI di MTs. Miftahul Ulum dan MTs. Annuriyah. Metode yang digunakan dalam penelitian ini adalah metode kualitatif, tehnik pengumpulan data yang digunakan adalah wawancara, observasi, dan dokumentasi.

Hasil penelitian dari penelitian ini adalah: 1) Strategi guru dalam memilih variasi metode pada pembelajaran SKI di Miftahul Ulum ini bermacam-macam diantaranya adalah: guru melihat kondisi kesehatan peserta didik; guru melihat kondisi psikologi peserta didik; guru melihat waktu yang dijadwalkan untuk mata pelajaran SKI, guru melihat isi materi pelajaran SKI yang akan disampaikan; 2) Respon peserta didik terhadap variasi metode pada pembelajaran SKI di MTs. Miftahul Ulum ditunjukkan dengan semangat belajar ketika pelajaran SKI disampaikan dengan menggunakan variasi metode pembelajaran, tidak mengantuk ketika mata pelajaran SKI disampaikan, merasa senang dan tidak jenuh ketika pelajaran SKI disampaikan dengan menggunakan bervariasi metode, merasa kurang terhadap jam pelajaran SKI yang diselenggarakan oleh sekolah, dan merasa perlu diadakan penambahan jam mata pelajaran SKI.
\end{abstract}

Kata kunci : variasi metode, pembelajaran SKI 


\section{A. PENDAHULUAN}

Artikel yang berjudul "Variasi Metode Pembelajaran Sejarah Kebudayaan Islam (SKI) di MTs. Miftahul Ulum Weding Bonang Demak merupakan penelitian hasil lapangan. Ini dimaksudkan untuk mendeskripsikan strategi guru dalam memilih variasi metode pada pembelajaran SKI serta mendeskripsikan respon peserta didik terhadap variasi metode pada pembelajaran SKI.

Pendidikan adalah usaha sadar dan terencana untuk mewujudkan suasana belajar dan proses pembelajaran agar peserta didik secara aktif mengembangkan potensi dirinya untuk memiliki kekuatan spiritual keagamaan, pengendalian diri, kepribadian, kecerdasan, akhlak mulia, serta keterampilan yang diperlukan dirinya, masyarakat, bangsa, dan Negara (UU RI No. 20 Tahun 2003 Pasal 1 Sisdiknas, 2016).

Sedangkan tujuan pendidikan nasional yaitu berkembangnya potensi peserta didik agar menjadi manusia yang beriman dan bertakwa kepada Tuhan Yang Maha Esa, berakhlak mulia, sehat, berilmu, cakap, kreatif, mandiri, dan menjadi warga negara yang demokratis serta bertanggungjawab (UU RI No. 20 Tahun 2003 Pasal 3 Sisdiknas, 2016).

Sewaktu kegiatan pembelajaran itu berproses semua kendala yang ditemui, boleh jadi menghambat jalannya proses pembelajaran apakah datangnya dari perilaku anak didik atau berasal dari luar diri anak didik yang mesti harus dihentikan.

Sehubungan dengan itu guru harus pandai menggunakan pendekatan secara arif dan bijaksana. Untuk itu sebaiknya guru memandang anak didik sebagai individu dengan segala perbedaannya antara anak didik yang satu dengan lainnya (Ramayulis, 2001). Mengacu pada penjelasan tersebut, menunjukkan bahwa suatu pembelajaran sangat diperlukan demi terjalinnya pendidikan yang baik. Maka dari itu dibutuhkan metode pengajaran yang baik, sehingga proses pengajaran dapat berjalan dengan lancar sesuai tujuan yang diinginkan.

Konsepsi pembelajaran modern menuntut peserta didik kreatif, responsif, dan aktif dalam mencari, memilih dan menemukan, menganalisis, menyimpulkan, dan melaporkan hasil belajar. Model pembelajaran seperti ini hanya dapat terlaksana dengan baik apabila guru mampu mengembangkan strategi pembelajaran yang efektif. Untuk itu dibutuhkan kreativitas guru dalam memilih metode pembelajaran yang efektif. Oleh karena itu, perlu dikaji pentingnya penggunaan variasi metode dalam pembelajaran, karena metode sangat membantu dalam mencapai tujuan pembelajaran. Sebagai seorang pendidik atau guru perlu merancang variasi metode untuk menyampaikan materi pembelajaran, dengan variasi metode yang tepat, peserta didik pun tidak merasa bosan dengan materi pembelajaran yang hendak disampaikan oleh pendidik atau guru sehingga tujuan pembelajaran pun akan tercapai dengan baik.

Berdasarkan tujuan dan latar belakang di atas, maka metode yang digunakan dalam penelitian ini adalah metode penelitian kualitatif yang mana teknik pengumpulan datanya dengan menggunakan teknik wawancara, observasi, dan dokumentasi.

\section{B. PEMBAHASAN}

\section{Mata Pelajaran Sejarah Kebudayaan Islam (SKI)}

Sebelum penulis jelaskan mengenai pengertian mata pelajaran SKI, penulis perlu jelaskan juga bahwa pelajaran SKI ini merupakan salah satu penjabaran dari Pembelajaran Pendidikan Agama Islam. Dimana untuk PAI biasanya digunakan pada lembaga pendidikan umum seperti SD, SMP, SMA, dan Perguruan Tinggi umum. Sedangkan pelajaran SKI ini biasanya 
digunakan pada Sekolah seperti SD Islam/MI, SMP Islam/ MTs, SMA Islam/ MA, dan Perguruan Tinggi Islam.

Pengertian sejarah menurut etimologi berasal dari bahasa Arab syajarah, artinya " pohon". Istilah lain dalam bahasa asing disebut histore (Perancis), geschicte (Jerman), histoire atau geschiedenis (Belanda), dan history (Inggris). Kata history sendiri dalam ilmu pengetehuan sebenarnya berasal dari bahasa Yunani (istoria) yang berarti pengetahuan gejala-gejala alam, khususnya manusia yang bersifat kronologis. Oleh karena itu sejarah dalam perspektif ilmu pengetahuan menjadi terbatas hanya mengenai aktivitas manusia yang berhubungan dengan kejadian-kejadian tertentu yang tersusun secara kronologis (Siti Maryam dkk, 2009)

Penjelasan di atas bisa penulis pahami pada bagian pengertian sejarah yang berasal dari bahasa Arab yaitu "syajarah", kata tersebut jika diterjemahkan dalam bahasa Indonesia berarti “pohon". Bisa dibayangkan biasanya pohon itu tumbuh menjulang tinggi keangkasa memiliki akar yang kokoh dan kuat, terdapat ranting, cabang, dan daun. Itu bisa diartikan bahwa sejarah itu memiliki masa, berkembang sesuai zaman. Yang paling penting adalah sejarah ibarat akar, dimana ada asal-usul pohon bisa hidup. Contoh adalah sejarah tentang kehidupan dengan asal-usul.

Suatu kejadian bisa dikatakan sebagai sejarah jika kejadian itu sudah lewat pada masa lampau. Untuk kejadian pada masa yang akan datang tidak bisa dikatakan sebagai sejarah karena manusia belum melewati masa itu. Jadi, sejarah itu ada kaitannya dengan masa atau waktu.

$\begin{array}{lrr}\text { Sedangkan } & \text { Kebudayaan adalah } \\ \text { bentuk ungkapan } & \text { tentang semangat } \\ \text { mendalam suatu masyarakat. } & \text { Menurut }\end{array}$

Koentjoroningrat, kebudayaan paling tidak mempunyai tiga wujud: (1) wujud ideal, yaitu wujud kebudayaan yang sebagai suatu kompleksitas ide-ide, gagasan, nilai-nilai, norma-norma, peraturan, dan sebagainya, (2) wujud kelakuan, yaitu wujud kebudayaan sebagai suatu kompleks aktivitas kelakuan berpola dari manusia dalam masyarakat, dan (3) wujud benda, yaitu wujud kebudayaan sebagai benda-benda hasil karya (Koentjaraningrat, 2015)

Sejarah kebudayaan Islam dilahirkan oleh umat Islam sekalipun tidak menggunakan istilah kebudayaan umat Islam. Islam itu bukan budaya karena Islam adalah wahyu dari Allah, sedangkan budaya Islam adalah hasil karya orang Islam.

Kebudayaan itu dimiliki oleh seluruh umat manusia dari segala level, termasuk masyarakat primitifpun berbudaya. Karena kebudayaan adalah hasil karya manusia. Sedangkan peradaban adalah pengembangan budaya manusia dengan kemampuannya untuk mengembangkan diri sesuai dengan pengembangan ilmu pengetahuan dan teknologi. Bagi pendidik perlu menyinggung tentang ini.

Dengan demikian, mata pelajaran sejarah kebudayaan Islam ialah bahan ajar yang digunakan dalam pembelajaran PAI yang membahas tentang kisah masa lampau manusia baik mengenai hasil pikiran, totalitas pikir maupun karya orang yang hidup dan bernaung di bawah panji-panji Islam yang didasarkan kepada pemahaman orang-orang Islam.

\section{Variasi Metode Pembelajaran}

Menurut Kamus Besar Bahasa Indonesia, kata variasi memiliki beberapa arti diantaranya adalah 1) tindakan atau hasil perubahan dari keadaan semula; selingan, 2) 
bentuk (rupa) yang lain; yang berbeda bentuk, 3) hiasan tambahan (Rama, tt)

Dari penjelasan mengenai variasi di atas, penulis lebih condong pada pengertian yang nomor dua untuk penerapan pada tulisan ini . Yaitu bentuk (rupa) yang lain; yang berbeda bentuk. Dalam arti dalam proses belajar mengajar menggunakan metode yang berbeda-beda.

Metode mengajar adalah cara yang digunakan guru dalam mengadakan hubungan dengan peserta didik pada saat berlangsungnya pengajaran (Halmar, 2006). Metode bisa dipahami secara sederhana sebagai suatu cara untuk melakukan sesuatu sesuai prosedur-prosedur tertentu.

Sedangkan pembelajaran menurut Sudjana dalam buku Psikologi Pendidikan dalam Sugihartono dkk menyebutkan bahwa pembelajaran merupakan setiap upaya yang dilakukan dengan sengaja oleh pendidik yang dapat menyebkan peserta didik melakukan kegiatan belajar (Sugiharto dkk, 2007). Bisa dikatakan bahwa hubungan antara peserta didik dan pendidik dalam proses belajarmengajar tidak bisa dipisahkan. Seorang pendidik membutuhkan peserta didik dan juga sebaliknya, seorang peserta didik juga membutuhkan peran seorang pendidik.

Dengan demikian, menurut analisis penulis bisa ditarik kesimpulan bahwa variasi metode ialah proses belajar mengajar guru tidak hanya menggunakan satu metode saja tetapi juga dengan variasi beberapa metode lain yang tepat untuk digunakan guru dalam menyampaikan materi pelajaran. Atau lebih ringkasnya, variasi metode pembelajaran bisa juga diartikan sebagai penggunaan beberapa metode dalam proses belajar mengajar.

Terdapat banyak macam metode yang bisa diterapkan dalam variasi metode pembelajaran, diantaranya: a. Metode ceramah + Tanya jawab + diskusi

b. Metode ceramah + diskusi + tugas

c. Metode ceramah + sosiodrama + sistem regu, dll (Ismail SM, 2011)

Berbagai macam variasi metode pembelajaran bisa dipilih dengan menyesuaikan materi, waktu, kondisi peserta didik maupun pendidik, dan lain-lain.

\section{Strategi Memilih Variasi Metode Pembelajaran}

Strategi mengajar (pengajaran) adalah "taktik" yang digunakan guru dalam melaksanakan proses belajar mengajar (pengajaran) agar dapat mempengaruhi para siswa (peserta didik) mencapai tujuan pengajaran (kompetensi dan indikator hasil belajar) secara lebih efektif dan efesien (Rohani, 2010). Penjelasan mengenai strategi mengajar menurut Ahmad Rohani tersebut menunjukkan bahwa pengajaran itu lebih mengarah pada pendidik sebagai transfer of knowlage, transfer of value, transfer of skill, harus bisa membawa peserta didik untuk memperoleh tujuan dari pengajaran secara maksimal.

Untuk pemilihan variasi metode pembelajaran, guru harus memperhatikan beberapa komponen strategi pembelajaran yang tersebut di atas. Selain itu juga guru sebagai pendidik juga harus memperhatikan empat strategi sebagai berikut dibawah ini: 
a. Mengidentifikasi, menetapakan spesifikasi dan kualifikasi perubahan tingkah laku dan kepribadian peserta didik sebagaimana yang diharapkan

b. Memilih sistem pendekatan pembelajaran sebagai landasan filosofis dalam pembelajaran

c. Memilih dan menetapkan prosedur, metode, dan teknik pembelajaran yang dianggap paling tepat dan efektif sehingga dapat dijadikan pegangan oleh guru dalam menunaikan kegiatan belajar

d. Menetapkan norma-norma dan batas minimal keberhasilan atau kriteria keberhasila sehingga dapat dijadikan pedoman oleh guru dalam melakukan evaluasi hasil kegiatan pembelajaran yang selanjutnya aka dijadikan umpan balik untuk penyempurnaan sistem instruksioanal secara menyeluruh (Djamarah, 2010)

Ke empat strategi tersebut di atas dilaksanakan secara berurutan dari strategi pertama hingga ke empat guna memperoleh hasil yang maksimal dalam sistem pembelajaran. Dalam melalui keempat strategi di atas, sangat dibutuhkan kecerdasan seorang pendidik guna untuk mengidentifikasi tingkah laku peserta didik, memilih sistem pendekatan pembelajaran, memilih dan menetapkan metode pembelajaran, serta menetapkan normanorma dan batas minimal keberhasilan pembelajaran.

\section{Kriteria Strategi Memilih Variasi Metode Pembelajaran}

Konsepsi pembelajaran modern menuntut peserta didik supaya lebih kreatif, responsive, dan aktif dalam mencari, memilih dan menemukan, menganalisis, menyimpulkan, dan melaporkan hasil belajar. Model pembelajaran seperti ini hanya dapat terlaksana dengan baik apabila guru mampu mengembangkan strategi pembelajaran yang efektif. Untuk itu dibutuhkan kreativitas guru dalam memilih berbagai metode pembelajaran yang sesuai sekaligus efektif.

Untuk itu, perlu diciptakan proses belajar yang bisa merangsang otak (kognitif), menyentuh dan menggerakkan perasaan (afektif), dan mendorong anak didik untuk melakukan kegiatan (motorik) serta sebisa mungkin peserta didik dituntut untuk menerapkan apa yang telah dipelajarinya (aplikatif) ketika menerima bahan pelajaran karena peserta didik harus bisa memanfaatkan berbagai sumber belajar dan memiliki kesempatan untuk mengungkapakan dan tidak hanya pasif hanya menerima saja (reseptif).

Ada enam kriteria yang harus diperhatikan oleh pendidik dalam rangka strategi memilih variasi metode pembelajaran yang baik, beberapa diantaranya yaitu:

a. Kesesuaian strategi pembelajaran dengan tujuan baik ranah kognitif, afektif, maupun psikomotorik, yang pada prinsipnya dapat menggunakan metode pembelajaran tertentu untuk mencapainya

b. Kesesuaian strategi pembelajaran dengan jenis pengetahuan

c. Kesesuaian strategi pembelajaran dengan sasaran. Siapakah peserta didik yang akan menggunakan metode pembelajaran, bagaimana karakteristiknya, berapa jumlahnya, bagaimana latar belakang pendidikannya, sosial ekonominya, bagaimana minatnya, motivasinya dan gaya belajarnya.

d. Kemampuan strategi pembelajaran untuk mengoptimalkan belajar peserta didik. Apakah metode pembelajaran digunakan untuk belajar individual, kelompok kecil, maupun kelompok besar (klasikal) ((Djamarah, 2010) 
Menurut penulis, beberapa kriteria di atas harus di telaah terlebih dahulu oleh pendidik sebelum memilih metode pembelajaran mana yang tepat dalam proses belajar-mengajar di sebuah sekolah, perguruan tinggi, maupun lembaga pendidikan lainnya. Dengan metode yang tepat, maka materi pembelajaran akan bisa terserap dan mudah dipahami oleh peserta didik sehingga tujuan pembelajaran akan tercapai dengan baik pula.

5. Strategi Guru dalam Memilih Variasi Metode pada Pembelajaran Sejarah Kebudayaan Islam (SKI) di di MTs. Miftahul Ulum

Pada keterangan hasil wawancara dengan kepala MTs. Miftahul Ulum Weding dijelaskan bahwa MTs. Miftahul Ulum ini hanya memiliki satu guru SKI yaitu Pak Setiyo Utomo, S.Sos.I. sehingga jam mengajar SKI full seminggu dari kelas VII sampai kelas IX. Di MTs. Ini hari liburnya adalah hari Jumat, sehingg jika Peneliti hendak melakukan penelitian maka selain hari jumat.

Untuk metode yang digunakan dalam pembelajaran SKI mengacu pada kondisi peserta didik, apakah peserta didik sedang dalam keadaan lelah, semangat, maupun sedang baik kondisi kesehatannya. Variasi metode dalam pembelajaran SKI sangat diperlukan supaya peserta didik tidak mengalami kejenuhan belajar di dalam kelas. Variasi metode yang diterapkan dalam peembelajaran SKI di MTs. Miftahul Ulum banyak ragamnya diantaranya adalah metode ceramah, tanya jawab, demonstrasi waktu menggunakan LCD, diskusi, tugas, regu, dan cerita. Model variasi digabungkan misal, ceramah 15 menit, kemudian memperlihatkan gambar bagaimana bisa masyarakat pada zaman jahiliyah itu menyembah berhala, dan lain sebagainya.
Sebelum variasi metode dalam pembelajaran SKI dilaksanakan maka guru menciptakan situasi yang kondusif supaya tertib.

Dari wawancara tersebut guru SKI lebih sering menggunakan variasi metode pada pembelajaran SKI. Banyak sekali variasi yang bisa digunakan guru untuk myampaikan materi pelajaran SKI di antaranya yang digunakan adalah metode ceramah, menghafal, tanya jawab, cerita, information search (mencari informasi sendiri baik dari perpustakaan maupun yang lain).

Dari penyampaian guru mengenai variasi yang digunakan oleh sudah sesuai dengan yang ada pada teori mengenai macam metode pembelajaran, yang belum digunakan adalah metode sosiodrama.

6. Respon Peserta Didik MTs. Miftahul Ulum Terhadap Strategi Guru dalam Memillih Variasi Metode pada Pembelajaran Sejarah Kebudayaan Islam (SKI)

Menurut para peserta didik di MTs. Miftahul Ulum, Pembelajaran SKI sangat menyenangkan dan tidak menjenuhkan. Apalagi yang mengajar adalah Pak Setiyo Utomo, beliau selalu membuat variasi metode dalam pembelajaran sehingga terasa menyenangkan dan tidak membosankan. Peserta didik kurang tahu apa nama metode yang digunakan oleh guru SKI, tetapi yang pasti para peserta didik merasa senang dengan variasi beberapa metode ketika belajar SKI, karena tidak membuat jenuh. Guru SKI sering menggunakan variasi beberapa metode pembelajaran ketika mengajar setidaknya minimal dua metode pembelajaran dalam satu kali pertemuan, sesuai kondisi peserta didik.

Dari keterangan di atas menunjukkan peserta didik merasa senang dengan variasi metode pada pembelajaran 
SKI yang diterapkan oleh guru SKI. Dengan variasi metode pembelajaran, peserta didik tidak merasa jenuh. Dan variasi metode ini sering digunakan pada pembelajaran SKI.

Peserta didik di MTs. Miftahul Ulum banyak yang suka dengan pelajaran SKI karena Pelajarannya enak dan menyenangkan, apalagi yang mengajar adalah Pak Utomo. Peserta didik paling suka belajar SKI di kelas ketika diceritakan sejarah sama Pak Utomo. Selain karena banyak cerita, Pak Utomo adalah guru yang asyik dalam menyampaikan pelajaran. Dalam arti, ngajarnya tidak begitubegitu saja, tetapi menggunakan bermacammacam cara penyampaian, kadang bercerita, kadang nonton film sejarah menggunakan proyektor LCD, kadang saling tanya jawab, guru bertanya peserta didik menjawab, dan lain-lain.

Dengan variasi metode pada pembelajaran SKI ini menjadikan peserta didik mudah berinteraksi dengan guru dan teman-teman sekelasnya. Jika perlu mata pelajaran SKI ditambah jam ngajarnya. Jam pelajaran SKI terasa sebentar sehingga peserta didik merasa kurang jam untuk materi SKI ini.

Peserta didik merasa mengantuk ketika belajar mata pelajaran SKI di kelas jika hanya dengan ceramah saja. Sebaliknya peserta didik tidak akan merasa mengantuk ketika guru merubah haluan dari hanya ceramah saja menjadi bervariasi metode pada pembelajaran SKI. Peneliti melihat secara langsung bagaimana kelas terasa hidup pada waktu pembelajaran SKI menggunakan bervariasi metode.

\section{PENUTUP}

Berdasarkan analisis data yang diperoleh peneliti, maka diambil kesimpulan bahwa:

1. Strategi guru dalam memilih variasi metode pada pembelajaran Sejarah SKI di MTs. Miftahul Ulum Weding Bonang Demak bermacam-macam diantaranya adalah: guru melihat kondisi kesehatan peserta didik; guru melihat kondisi psikologi peserta didik; guru melihat waktu yang dijadwalkan untuk mata pelajaran SKI, guru melihat isi materi pelajaran SKI yang akan disampaikan.

2. Respon peserta didik terhadap variasi metode pada pembelajaran SKI di MTs. Miftahul Ulum Weding Bonang Demak ditunjukkan dengan semangat belajar ketika pelajaran SKI disampaikan dengan menggunakan variasi metode pembelajaran, tidak mengantuk ketika mata pelajaran SKI disampaikan dengan bervariasi metode, merasa senang dan tidak jenuh ketika pelajaran SKI disampaikan dengan menggunakan bervariasi metode, merasa kurang terhadap jam pelajaran SKI yang diselenggarakan oleh sekolah, dan merasa perlu diadakan penambahan jam mata pelajaran SKI. 


\section{DAFTAR PUSTAKA}

Abdul Qadir Ahmad, Muhammad. (2008). Metodologi Pengajaran Agama Islam. Jakarta: Rineka Cipta.

Abdurrahman, Dudung. (1999). Metode Penelitian Sejarah. cet ke-2. Jakarta: PT.Logos Wacana Ilmu.

Ahmad D, Marimba. 1989. Pengajaran Filsafat Pendidikann Islam. Bandung: PT. al Maarif.

Arifin, Muzayyin. (2009). Filsafat Pendidikan Islam. cet.IV. Jakarta: PT.Bumi Aksara.

Arifin, Zaenal. (2009). Evaluasi Pembelajaran. Bandung: PT. Remaja Rosdakarya.

Arikunto, Suharsimi. (1991). Pengelolaan Kelas dan Siswa, Sebuah Pendekatan Evaluatif. Cet-2. Bandung: Remaja Rosda Karya.

Asnawi, Muh. (2009). Sejarah Kebudayaan Islam Jilid 3 Kelas IX. Semarang: CV. Aneka Ilmu Anggota IKAPI.

Asrohah, Hanun. (2001). Sejarah Pendidikan Islam. cet. Ke-2. Ciputat: PT. Logos Wacana Ilmu.

B.Uno, Hamzah. (2007). Perencanaan Pembelajaran. cet.ke-2. Jakarta: PT Bumi Aksara.

Darajat, Zakiah dkk. (1995). Metodologi Pengajaran Agama Islam. cet. 1. Jakarta: PT Bumi Aksara,

Darodjat, Zakiah. (1995). Metode Khusus pengajaran Agama Islam. Jakarta: PT. Bumi Aksara.

Darul, Muhammad. (2016). Studi Analisis Variasi Gaya Mengajar Guru Dalam
Meningkatkan

Kemampuan

Psikomotorik Siswa Pada Mata Pelajaran Fiqih Di Mi Datuk Singaraja Kerso Kedung Jepara Tahun Pelajaran 2015/2016. Skripsi. Kudus: STAIN.

Dekdikbud. (1990). Kamus Besar Bahasa Indonesia: Tim Penyusun Kamus Pusat Pembinaan dan Pengembangan Bahasa. Jakarta: Balai Pustaka.

Departemen Agama RI. (2005). Al-Quran dan Terjemahnya, Bandung, CV. Penerbit Jumanatul Ali Art, Dewi Aisyah, (2016), Metode Pembelajaran Pendidikan Agama Islam (PAI) di Sekolah Inklusi SDN Bendan 01 Pekalongan. Skripsi, Pekalongan: STAIN.

Djamarah, Syaiful Bahri. (2010). Guru dan Anak Didik dalam Interaksi Edukatif. Jakarta: P'T.Rienika Cipta.

Ghazali, Abu Hamid. Ihya' Ulum al-din, Juz I, Libanon: PT. Dar al-Kutub alIlmiyah Bairut.

Halmar, Mustopa. (2006). Strategi Belajar Mengajar. Semarang: Unissula Press.

Hamalik, Oemar. 1991. Pendekatan Baru Strategi Belajar Mengajar Berdasarkan CBSA. Bandung: Sinar Baru.

Hasjmy.A. (1979). Sejarah Kebudayaan Islam. cet. ke-2. Jakarta: Bulan Bintang.

Himpunan Perundang-Undangan Republik Indonesia Tentang Guru Dan Dosen. (2006). Bandung: CV. Nuansa Aulia.

Ismail SM. (2011). Strategi Pembelajaran Agama Islam berbasis Paikem :Pembelajaran Aktif, Inovatif, Kreatif, dan Menyenangkan. Semarang: Rasail Media Guru. 
Janu, Arni Wulandari. (2016). Pelaksanaan Variasi Metode dalam Pembelajaran Aqidah Akhlak di Madrasah Aliyah Negeri (MAN) Gubug. Skripsi. Semarang: UIN Walisongo.

Khaliq, Abdul dkk. (1999) Pemikiran Pendidikan Islam: Kajian Tokoh Klasik dan Kontemporer. Yogyakarta: Fakultas Tarbiyah IAIN Walisongo Semarang bekerjasama dengan Pustaka pelajar.

Koentjaraningrat. (2015). Kebudayaan, Mentalitas, dan Pembangunan. Jakarta: PT. Gramedia Pustaka Utama.

Langgulung, Hasan. (1992). Manusia dan Pendidikan Suatu Analisa Psikologi Pendidikan. Jakarta: Pustaka al Husna.

Majid, Abdul dan Dian Andayani. (2005). Pendidikan Islam Berbasis Kompetensi (Konsep dan Implikasi Kurikulum. Bandung: PT. Rosdakarya.

Maryam, Siti dkk. 2009). Sejarah Peradaban Islam: Dari Masa Klasik Hingga Modern. cet ke-3 Yogyakarta: LESFI.

Nata, Abuddin. (2014). Studi Islam. Jakarta: PT.Raja Grafindo Persada.

Nasution, S. (1992). Metode Penelitian Naturalistik-Kualitatif. Bandung: Tarsito.

Rama K, Tri. (tt). Kamus Lengkap Bahasa Indonesia. Surabaya:Karya Agung.

Ramayulis. 2001. Metodologi Pengajaran Agama Islam. Jakarta: Radar Jaya Offset Jakarta.
Ramayulis, dan Samsul Nizar. (2011). Filsafat Pendidikan Islam: Telaah Sistem Pendidikan dan Pemikiran Para Tokohnya. Jakarta: Radar Jaya Offset Jakarta

Rohani, Ahmad HM. (2010). Penelitian Kuantitatif dan Kualitatif Aspek Metodologi. (Outline Buku). Semarang.

Rohani, Ahmad HM. (2010). Pengelolaan Pengajaran. Cet. I. Jakarta: PT Renika Cipta.

Riezqi Prasetyo, Lutfi. (2011). Implementasi variasi metode pembelajaran IPS di SMP Darul Ma'rif Jakarta. Skripsi. Jakarta: Uin Syarif Hidayatullah.

Sanjaya, Wina. (2008). Pembelajaran dalam Implementasi Kurikulum Berbasis Kompetensi. cet ke-3. Jakarta: Prenada Media Group.

Sudjana, Nana. (2009). Dasar-dasar Proses Belajar Mengajar. Bandung: Sinar Baru Algensindo.

$\begin{array}{crr}\text { Susanto, Basri. } & (2009) . & \text { Efektivitas } \\ \text { penggunaan } & \text { variasi } & \text { metode } \\ \text { Pembelajaran } & \text { PAI } & \text { Dan } \\ \text { Hubungannya } & \text { Dengan } & \text { Motivasi } \\ \text { Belajar Siswa } & \text { Di SMP } & \text { Azzahra } \\ \text { Pondok Petir } & \text { Sawangan } & \text { Depok. } \\ \text { Skripsi. Jakarta: Uin } & \text { Syarif } \\ \text { Hidayatullah. } & & \end{array}$

Sugiharto. dkk. (2007). Psikologi Pendidikan. Yogyakarta: UNY Press.

Sugiyono. (2012). Metode Penelitian Kuantitatif, Kualitatif, dan R\&D. Cet ke 17. Bandung: IKAPI.

Suyanto. (1995). Efektivitas Dan Kualitas Sekolah, makalah disampaikan dalam Upaya Peningkatan Mutu SMU dan 
Penuntasan Wajar 9 Tahun. Yogyakarta: IKIP Yogyakarta.

Syalabi, A. (1994). Sejarah dan Kebudayaan Islam. Terj. Mukhtar Yahya, dkk. Jilid I. Jakarta: Pustaka al Husna.

Tafsir, Ahmad. (1992). Ilmu Pendidikan dalam Perspektif Islam. Bandung: Rosda Karya.

Tafsir, Ahmad. (2008). Metodologi Pengajaran Agama Islam. Bandung: Rosda Karya.

Tim Dosen PAI. (2014). Studi Islam I. Cet IX. Semarang: PT. LKPI.

Undang-Undang Republik Indonesia Nomor 20 Tahun 2003 Tentang Sisdiknas dan Peraturan Pemerintah RI Tahun 2015 Tentang Standar Nasional Pendidikan serta Wajib Belajar, Bandung:Citra Umbara. 2016

Undang-Undang Republik Indonesia Nomor 14 Tahun 2005 Tentang Guru dan Dosen, cet. I. Jakarta: CV. Biro Hukum Dan Organisasi Sekretariat Jendral Departemen Pendidikan Nasional. 2006

Utami, S.C. Munadar. (1986). Mengembangkan Bakat dan Kreativitas Anak Sekolah Petunjuk Bagi Guru Dan Orang Tua. Jakarta: PT.Gramedia.

Yatim, Badri. (1997). Sejarah peradaban Islam. Jakarta: PT. raja Grafindo persada.

Zuhairini, dkk. (2006). Sejarah Pendidikan Islam. Jakarta: Bumi Aksara.

Zuhairini, Abdul Ghofir dan Slamet As.yusuf. (1981). Methodik Khusus Pendidikan Agama. Surabaya: Biro Ilmiah
Fakultas Tarbiyah IAIN Sunan Ampel Malang. 